\title{
Evidence and Therapeutic Perspectives in the Relationship between the Oral Microbiome and Alzheimer's Disease: A Systematic Review
}

\author{
Yoann Maitre ${ }^{1,2}$, Rachid Mahalli ${ }^{3}$, Pierre Micheneau ${ }^{3}$, Alexis Delpierre ${ }^{3}$, Gilles Amador 4 \\ and Frédéric Denis $3,4,5, *$ \\ 1 Emergency Department, Montpellier University Hospital, 34090 Montpellier, France; maitreyoann@yahoo.fr \\ 2 EA 2415, Aide à la Décision pour une Médecine Personnalisée, Université de Montpellier, \\ 34093 Montpellier, France \\ 3 Department of Odontology, Tours University Hospital, 37000 Tours, France; \\ rachid.mahalli@etu.univ-tours.fr (R.M.); pierre45892@gmail.com (P.M.); alexis.delpierre@outlook.fr (A.D.) \\ 4 Faculty of Dentistry, Nantes University, 44000 Nantes, France; gilles.amador@univ-nantes.fr \\ 5 EA 75-05 Education, Ethique, Santé, Faculté de Médecine, Université François-Rabelais, 37044 Tours, France \\ * Correspondence: frederic.denis@chu-tours.fr; Tel.: +33-6-7715-6968
}

check for

updates

Citation: Maitre, Y.; Mahalli, R.; Micheneau, P.; Delpierre, A.; Amador,

G.; Denis, F. Evidence and

Therapeutic Perspectives in the

Relationship between the Oral

Microbiome and Alzheimer's Disease: A Systematic Review. Int. J. Environ. Res. Public Health 2021, 18, 11157. https://doi.org/10.3390/ ijerph182111157

Academic Editor: Florence Carroue

Received: 4 October 2021

Accepted: 21 October 2021

Published: 24 October 202

Publisher's Note: MDPI stays neutral with regard to jurisdictional claims in published maps and institutional affiliations.

Copyright: (c) 2021 by the authors. Licensee MDPI, Basel, Switzerland. This article is an open access article distributed under the terms and conditions of the Creative Commons Attribution (CC BY) license (https:// creativecommons.org/licenses/by/ $4.0 /)$.

\begin{abstract}
This review aims to clarify the nature of the link between Alzheimer's disease and the oral microbiome on an epidemiological and pathophysiological level, as well as to highlight new therapeutic perspectives that contribute to the management of this disease. We performed a systematic review, following the Preferred Reporting Items for Systematic Reviews checklist, from January 2000 to July 2021. The terms "plaque," "saliva," and "mouth" were associated with the search term "oral diseases" and used in combination with the Boolean operator "AND" / OR". We included experimental or clinical studies and excluded conferences, abstracts, reviews, and editorials. A total of 27 articles were selected. Evidence for the impact of the oral microbiome on the pathophysiological and immunoinflammatory mechanisms of Alzheimer's disease is accumulating. The impact of the oral microbiome on the development of $\mathrm{AD}$ opens the door to complementary therapies such as phototherapy and/or the use of prebiotic compounds and probiotic strains for global or targeted modulation of the oral microbiome in order to have a favourable influence on the evolution of this pathology in the future.
\end{abstract}

Keywords: Alzheimer's disease; oral microbiota; oral microbiome; mental disorders

\section{Introduction}

Alzheimer's disease (AD) is progressive and neurodegenerative in the elderly ( $>65$ years old), in which the main symptom is a decline in cognitive ability, severe enough to interfere with daily living activities. Approximately 47 million people worldwide have AD-related dementia, and this number has doubled almost every 20 years. It is expected to reach 131.5 million by 2050 [1].

AD is characterized by protein conformation [2,3], mainly caused by aberrant processing and polymerization of normally soluble proteins [4]. When misfolded, soluble neuronal proteins reach altered conformations, due to genetic mutations (Apolipoprotein $\varepsilon 4$ gene (APO $\varepsilon 4$ ) is the most important risk factor in sporadic AD), external factors like aging and aggregates, lead to abnormal neuronal function and neuronal loss [2-5]. To date, AD causes are still poorly understood and, although many treatments have been tested in clinical trials, none can cure or stop its progression.

However, it was established that even before the first symptoms appear, neurons are affected by two types of lesions: amyloid plaques located between neurons and neurofibrillary degeneration, which is located inside neurons [6]. Amyloid plaques are formed by the abnormal accumulation of a protein called " $\beta$-amyloid" between nerve cells in 
the grey matter of the cerebral cortex, with a dysfunction of the connections between neurons [7]. Neurofibrillary degeneration corresponds to an abnormal accumulation of filaments inside the neuron; the protein responsible for this dysfunction is called "Tau protein" [8]. Both lesions are clusters of proteins that form during the normal aging process. Yet, in Alzheimer's type disease, these proteins accumulate in much larger quantities [9].

$\mathrm{AD}$ is considered a multifactorial disease, with its onset thought to result from the interaction between genetic background and various risk factors [10]. Age is the main proven risk factor, with a prevalence that doubles every 5 years from the age of 65 years ( $2 \%$ after $65,15 \%$ after 80 years) [1]. Other risk factors are now well-established, such as low level of education, cardiovascular risk factors (untreated hypertension, stroke, hypercholesterolemia, diabetes, overweight status, obesity, and periodontal disease); women; environmental factors (tobacco, alcohol, pollution, certain drugs); and sleep disorders. Chronic inflammation of the body is linked to shrinkage of brain areas in AD; mood disorders like chronic stress or depression are also correlated. An unbalanced diet, lack of physical and stimulating mental activity may also be associated with an increased risk of AD [11-13].

Recently, many studies show epidemiological correlations between AD and periodontitis. There are also pathophysiological arguments for a causal relationship between AD and periodontal disease (PD) $[14,15]$. Periodontitis is a peripheral infectious/inflammatory condition, one of the major risk factors in tooth loss [16]. Periodontitis is associated with increased serum levels of C-reactive protein (CRP) and pro-inflammatory cytokines (e.g., tumor necrosis factor- $\alpha$ ), as well as decreased anti-inflammatory markers (e.g., interleukin10) [17]. Many researchers hypothesised that the association between $A D$ and periodontitis may be due to increased systemic inflammation accompanying the growth of periodontal pathogens $[18,19]$. The latter would mediate the development of AD through their role in the development of vascular disease [14,20,21].

Although the link between gut dysbiosis and neurological disorders remains speculative, anatomical evidence is leading to a better understanding of a bidirectional link between the gut and brain, as is the case in $\mathrm{AD}[22,23]$. This bidirectional relationship is thought to exist between the oral microbiota and many systemic diseases, including AD.

This review aims to clarify the nature of the link between Alzheimer's disease and the oral microbiome at the epidemiological and pathophysiological levels, as well as to highlight new therapeutic perspectives to contribute to the management of this disease.

\section{Materials and Methods}

We performed a systematic review following the Preferred Reporting Items for Systematic Reviews (PRISMA) checklist [24]. Authors defined research questions, objectives, search strategies, and inclusion/exclusion criteria through previous discussions.

\subsection{Search Strategy}

Understanding the interactions of microorganisms with the host and with each other, as well as their impact on health, was improved by the development of high-throughput sequencing techniques for genetic material since 2000 [25]. The research was carried out from January 2000 to July 2021 to clarify the relationship between AD and the oral microbiome. So as not to restrict the search only to oral pathologies, terms identifying the main oral ecological niches "Dental plaque," "Saliva," and Mouth" were associated with the search term "Mouth diseases" and used in combination with the Boolean operator "AND" /"OR" as per the following equation:

(((“"Mouth"[Mesh]) OR “Mouth Diseases”[Mesh]) OR “Dental Plaque"[Mesh]) OR "Saliva"[Mesh]) AND “Alzheimer Disease"[Mesh]

The search was performed in the MEDLINE literature database through PubMed interface. 


\subsection{Inclusion and Exclusion Criteria}

We included experimental or clinical studies (longitudinal, cross-sectional, or randomised) that explored the association between the oral microbiome and AD symptoms, and/or explored the association between the oral microbiome and AD from an immunoinflammatory perspective. We excluded conferences, abstracts, reviews, and editorials.

\subsection{Data Extraction}

Two independent operators (F.D. and Y.M.) manually checked the references of eligible studies on the subject, according to inclusion/exclusion criteria.

An analysis of titles and abstracts by F.D. and Y.M. was performed to identify potentially relevant articles based on inclusion criteria. When the information in the abstracts was deemed insufficient, a review of the complete study decided on its relevance. A discussion between the two reviewers took place to reach a consensus with discrepancies in the selection decision process.

\section{Results}

\subsection{Study Selection}

After retrieving the studies from the database, we identified the studies that met eligibility criteria. Of the 227 studies initially identified, 24 were selected. A complementary detection resulted in the selection of three additional articles. A total of 27 articles were included in the analysis (Figure 1).

\subsection{Study Characteristics}

Since the beginning of 2000, the number of publications about the relationship between the oral microbiome and $\mathrm{AD}$ has been steadily increasing, with $44 \%$ of publications from 2019 to 2021 (Figure 2a). These concern experimental in vitro studies $(\mathrm{n}=1)$ or murine models $(n=6)$ and human clinical studies $(n=20)$. The case-control study design is most often used for human studies $(n=12)$ (Figure $2 b)$. With the exception of retrospective cohort studies, sample sizes were limited in both animal $(\mathrm{N}=30$ to 140) and human ( $N=20$ to 354) studies. While they were conducted worldwide, they were concentrated in the United States (9 studies from 2002 to 2021) and in Europe (8 studies from 2010 to 2021) see Figure 2c.

Each study meeting the inclusion criteria was analysed in terms of authors, date of publication, study design, objectives, factors assessed, results and limitations (Table 1).

\subsection{Clinical Oral Perturbations and Alzheimer's Disease}

In 2020, Kantarci et al. showed that PD increases bone loss in AD model mice (5xFAD) and wild-type control mice (WT). While they found no significant difference in alveolar bone loss after induction of experimental PD between 5xFAD and WT mice, they noted that alveolar bone loss is higher in 5xFAD than in WT at baseline [26].

Periodontal damages were also identified in several case-control studies in humans. Thus, De Oliveira Araújo et al. found a significant association between periodontitis and $\mathrm{AD}$, controlling for age, sex, income, and education [27]. In accordance with this result, periodontal infections, the presence of deep periodontal pockets, and generalised marginal alveolar bone loss are markers of periodontal deterioration, that appear to be significantly associated with AD patients [28-31]. Similarly, in 2015, the cross-sectional study by Kamer et al. found a significant association between a loss of clinical attachment and increased amyloid load in vulnerable brain areas of AD patients, after adjustment for confounding factors (age, ApoE, and smoking) [15].

Several retrospective cohort studies, assessing the association between incident AD risk and PD, moderate these results. For example, in a cohort followed for 26 years $(\mathrm{N}=6650)$, the association between risk of $\mathrm{AD}$ and periodontal pocket depth appeared marginal in men and older individuals [32]. The study by Choi et al. shows that in a cohort of 262,349 participants aged 50 or older with a follow-up of 11 years, developing 
$\mathrm{AD}$ tends to be higher in patients with chronic periodontitis (CP), vs. patients without $\mathrm{CP}$ $(\mathrm{aHR}=1.05 ; 95 \% \mathrm{CI}=1.00-1.11, p=0.042)$ [21]. Conversely, in a cohort of 27,963 patients over 50 years, followed for 16 years, Chen et al. showed a significantly higher risk of developing $\mathrm{AD}$ in patients with 10 years of exposure to $\mathrm{CP}$ vs. those with no exposure [33].

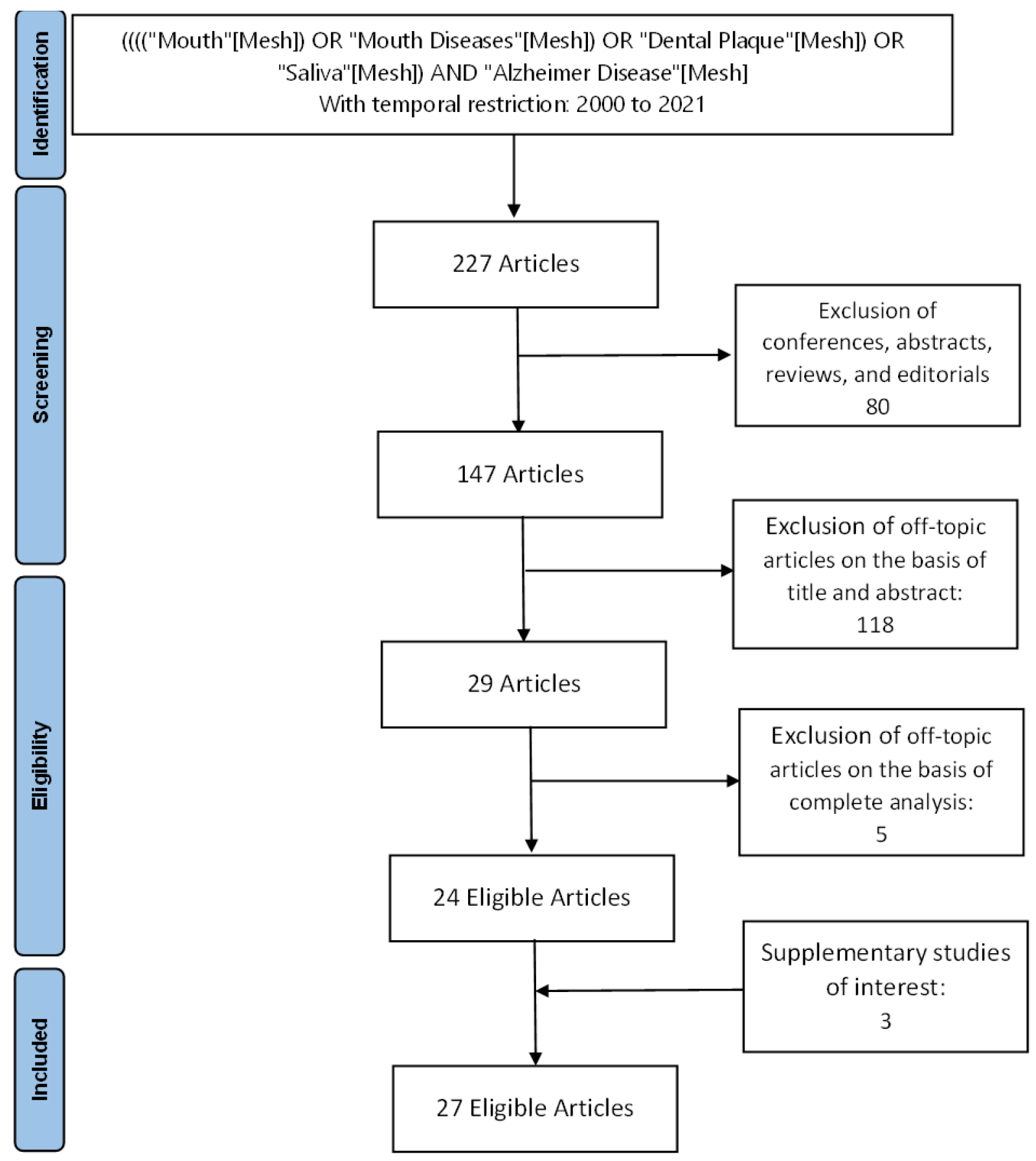

Figure 1. Flow chart of the study selection. 
a)

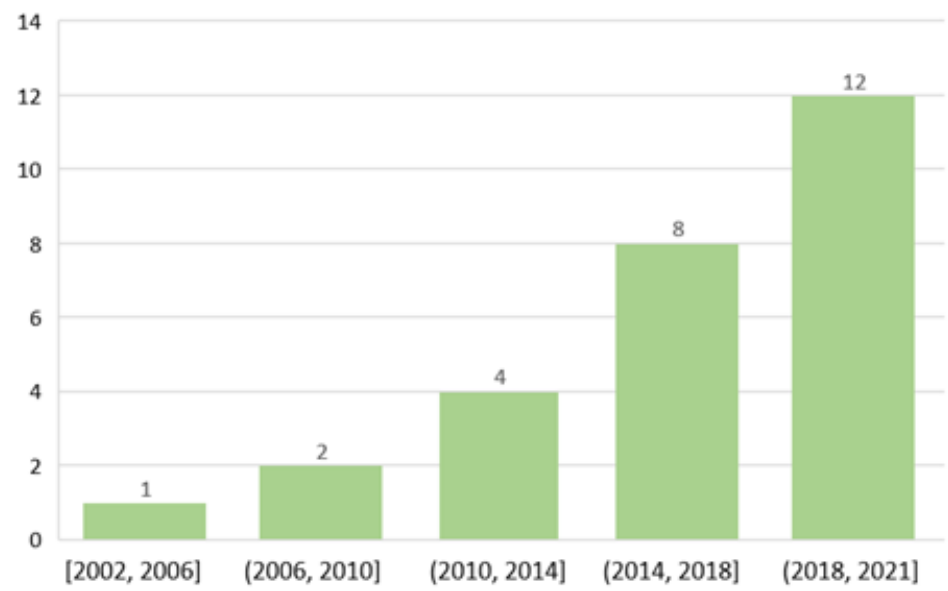

b)

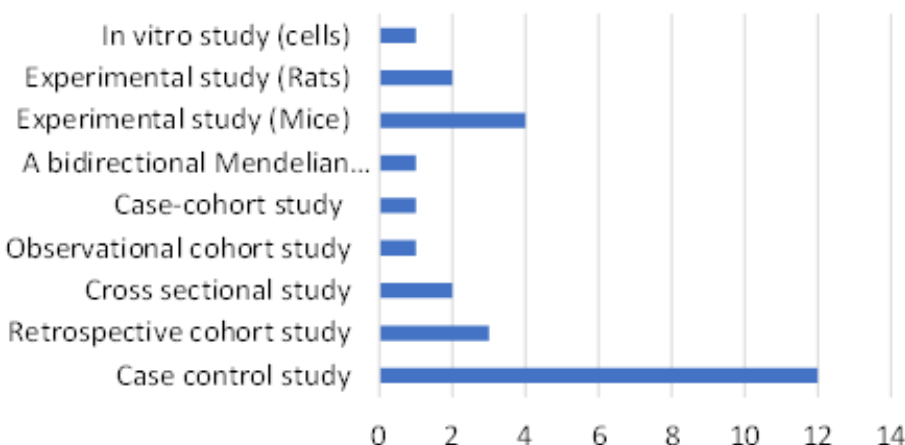

c)

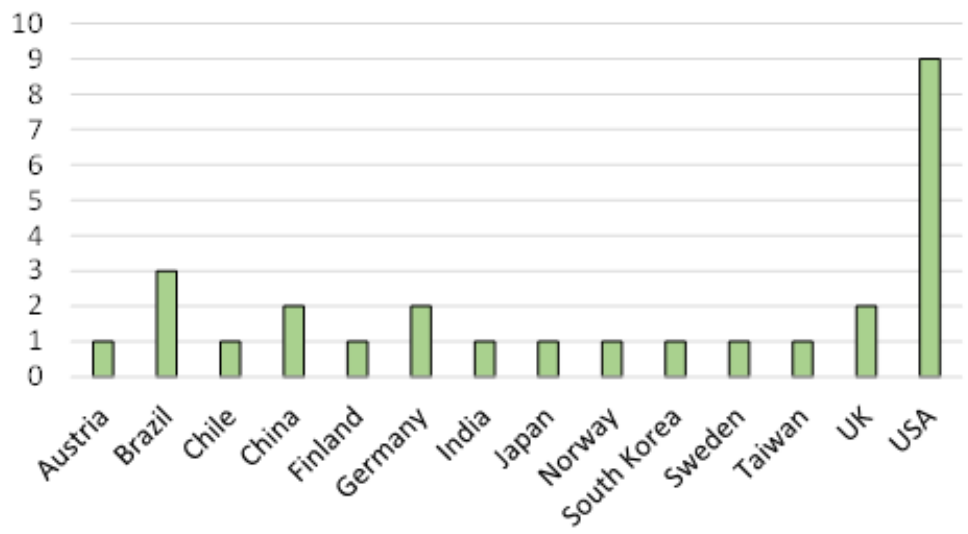

Figure 2. Study characteristics: years of publication (a), design, (b), research laboratory country (c).

\subsection{Oral Dysbiosis and Alzheimer's Disease}

Liu et al. showed that the salivary microbiome has significantly lower diversity in patients with AD than in healthy patients [34]. Maurer et al. also identified a higher bacterial load of Aggregatibacter actinomycetemcomitans, Porphyromonas gingivalis, and Fusobacterium nucleatum in dental plaque compared to controls [35]. Rivière et al. demonstrated that brain colonisation by treponemes (T. amylovorum, T. denticola, T. maltophilum, T. medium, T. pectinovorum, T. socranskii, T. vincentii) was more frequent in AD patients than controls [36]. In 2018, Ilievski et al. detected the presence of $P$. gingivalis and gingipain in the hippocampus of mice [37].

While the study by Liu et al. concluded that no oral bacteria are associated with the severity of AD [34], serum immunoglobulin G (IgG) concentration associated with common periodontal bacteria (P. gingivalis, Tannerella forsythia, A. actinomycetemcomitans, T. denticola, Campylobacter rectus, Actinomyces naeslundii) represents a risk factor in developing AD [38]. 
According to the study by Beydoun et al., the incidence and mortality of AD could be related to a combination of periodontal bacteria. The incidence of $\mathrm{AD}$ is related to a composite of $C$. rectus and $P$. gingivalis, such that the risk of mortality from AD was enhanced by a composite of $P$. gingivalis, Prevotella intermedia, Prevotella nigrescens, F. nucleatum, C. rectus, Streptococcus intermedius, Capnocytophaga ochracea and Prevotella melaninogenica [32].

\subsection{Pathophysiological Evidence between the Microbiome and Alzheimer's Disease}

According to the study of Dominy et al., on mice, the presence of $P$. gingivalis and gingipaïn in the brain plays a central role in the pathogenesis of AD [39]. In vitro, Yamada et al. demonstrated that exposure to phosphoglycerol dihydroceramide produced by $P$. gingivalis (PGDHC) increased $\mathrm{A} \beta$ peptide secretion in a dose-dependent manner in the Chinese hamster ovary-7WD10 cells, stably expressing wild-type human amyloid precursor protein (APP) and induced specific phosphorylation of Tau protein in a dose-dependent manner in human neuroblastoma cells [40]. In rats, Zhang et al. showed a significant elevation of $A \beta 1-40$ peptide levels in the cerebral cortex of $A D$ rats with periodontitis compared to AD rats without it [41]. Similarly, Díaz-Zúñiga et al. observed a significant increase in A $31-42$ levels and Tau hyperphosphorylation in the hippocampus of rats orally infected by K1 or K2 P. gingivalis, associated with PD [42]. In mice, Kantarci et al. noted a significant elevation of the mean level of insoluble $A \beta 42$ peptide in the prefrontal cortex of AD mice with periodontitis, compared to AD mice without it [26]. Phosphorylation of Tau protein was detected by Ilievski et al. (2018) in AD mice infected with P. gingivalis, but not in control mice [37].

Studies of cognitive decline in murine models show no significant differences in learning and memory tests (Y maze, nest building, or the Morris Water Maze test) that may be associated with periodontitis or acute or continuous exposure to $P$. gingivalis-derived lipopolysaccharides (Pg-LPS) [41,43]. According to Ide et al., there was also no significant relationship between serum levels of antibodies to $P$. gingivalis and rates of cognitive decline, based on the Mini Mental State Examination (MMSE) in AD patients [19]. However, in 2020, Leblhuber et al. found a significant association between the salivary presence of $P$. gingivalis and lower MMSE in AD patients [44].

\subsection{Oral Microbiota and Immuno-Inflammation in Alzheimer Disease}

While neuroimmune interactions are essential to brain function [45], chronic inflammation appears to be a key factor in the pathophysiology and clinical progression of AD [46]. In vitro, Yamada et al. showed that exposure of human neuroblastoma cells to PGDHC or Pg-LPS increased expression of the senescence-associated secretory phenotype involving $\beta$-galactosidase, cathepsin B, cysteine, and pro-inflammatory cytokines TNF- $\alpha$ and IL-6 [40].

In the hippocampus of rats infected with $P$. gingivalis encapsulated serotypes K1 and K2, Díaz-Zúñiga et al. observed a significant increase in pro-inflammatory cytokine (IL-1 $\beta$, IL-6, TNF- $\alpha$, IFN- $\gamma$ ) not found in rats infected with non-encapsulated bacterial strains [42]. Similarly, oral application of $P$. gingivalis 3 times a week for 22 weeks showed a significant increase in the expression of pro-inflammatory cytokines (IL-1 $\beta$, IL-6 and TNF- $\alpha$ ) in the hippocampus of infected mice compared to controls [37]. In AD model rats with induced periodontitis, compared to controls, TNF- $\alpha$ levels were significantly higher in the hippocampus, IL-1 levels were higher in the cerebral cortex, and IL6 levels were higher both in the hippocampus and cerebral cortex [41]. The inflammatory activation index (TNFa to IL-10 ratio) shows higher and unresolved inflammation in the brains of AD mice before and after induction of periodontitis, than in non-AD mice; this is associated with a reduction in microglial markers in the vicinity of $A \beta$ plaques, vs. those without induced periodontitis [26].

Consistent with the study by Kamer et al., which showed a higher expression of antibodies against periodontal bacteria (A. actinomycetemcomitans, T. forsythia, and P. gingivalis) and TNF- $\alpha$ in the serum of AD patients than controls [47]; Cestari et al. noted a significant 
association between periodontitis and increased serum levels of TNF- $\alpha$ and IL- 6 in AD patients [48]. Over a six-month follow-up in patients with mild to moderate AD, anti-P. gingivalis antibody levels were associated with a fall in serum IL10 levels and an increase in serum TNF $\alpha$ [19]. In short-term post-mortem AD brain tissue (12h), Poole et al. (2013) detected the presence of Pg-LPS and suggests their role in brain inflammation associated with AD [49]. Similarly, Laugish et al. (2018) showed in patients with AD or other forms of dementia that high levels of antibodies against periodontal bacteria in cerebrospinal fluid and serum (A. actinomycetemcomitans, T. denticola, T. forsythia, P. gingivalis) can play a significant role in the local immune response [50]. In AD patients, a significant reduction in the concentration of sensitive biomarkers of immune activation is associated with different oral bacteria; thus, the presence of T. denticola and T. forsythia in saliva reduced the serum concentrations of neopterin and kynurenine, respectively [44].

\subsection{Alzheimer's Disease Risk Factor and Therapeutic Perspectives in Relation to the Oral Microbiome}

The influence of genetics on the onset and development of AD, as well as on susceptibility to pathogens is well-understood [51,52]. In 2019, Liu et al. study found a significant decrease in Actinobacillus and Actinomyces levels and an abundance of Abiotrophia and Desulfomicrobium in patients carrying the APOE $\varepsilon 4$ gene [34]. In $P$. gingivalis-infected mice, the expression of APP and BACE1 genes, involved in the development of AD, was significantly increased vs. the control group. Conversely, the expression of ADAM10, which plays an essential role in reducing the generation of amyloid- $\beta(A \beta)$ peptides, was significantly reduced [37]. The Mendelian randomization study of Sun et al. (2020) found no evidence for a bidirectional genetic relationship between $\mathrm{AD}$ and periodontitis from analysis of data from Genome-Wide Association Studies in the European ancestry population [53]. According to Kamer et al., no significant difference in cytokine levels could be found as per the presence of the APOE $\varepsilon 4$ gene in AD patients [47].

Several studies suggest that antimicrobial therapy is effective for AD [54], but only one study on modulation of the oral microbiome was identified. In the study by Dominy et al., oral administration of gingipain inhibitors to mice, essential for the survival of $P$. gingivalis, reduced the load of $P$. gingivalis and cytokines (TNF $\alpha)$, as well as the production of $A \beta$ peptide 1-42 in the brain. An increased number of neurons in the hippocampus of $P$. gingivalis-infected mice, treated with these inhibitors, reflects a reduction in the neurotoxicity of this bacterium [39]. 
Table 1. Analysis of selected articles.

\begin{tabular}{|c|c|c|c|c|}
\hline Reference(s) & Study Design & Objectives & Evaluated Factors & Mains Results and Limitations * \\
\hline $\begin{array}{l}\text { Riviere et al., } 2002 \\
\text { [36] }\end{array}$ & $\begin{array}{l}\text { Case control study } \\
\mathrm{N}=38 / 40\end{array}$ & $\begin{array}{l}\text { Assessment of the oral treponema } \\
\text { presence in the human brain, the } \\
\text { hippocampus and the trigeminal } \\
\text { ganglia in AD patients and controls. }\end{array}$ & $\begin{array}{l}\text { T. denticola, Treponema amylovorum, } \\
\text { Treponema maltophilum, T. medium, } \\
\text { Treponema pectinovorum, Treponema } \\
\text { socranskii, T. vincentii }\end{array}$ & $\begin{array}{l}\text { Detection of oral Treponema in brainstem, cortex } \\
\text { and trigeminal ganglia in human subjects with } \\
\text { Alzheimer's disease. } \\
\text { AD patients had more different Treponema } \\
\text { species in the brain than controls. } \\
\text { Treponema brain colonisation significantly more } \\
\text { frequent in patients with Alzheimer's disease } \\
\text { than in controls. } \\
\text { * Possibility of a post-mortem contamination of } \\
\text { tissues or assays }\end{array}$ \\
\hline $\begin{array}{l}\text { Kamer et al., } 2009 \\
\text { [47] }\end{array}$ & $\begin{array}{l}\text { Case-control study } \\
\mathrm{N}=18 / 16\end{array}$ & $\begin{array}{l}\text { Evaluation of the difference in } \\
\text { concentration of TNF } \alpha \text { and } \\
\text { antibodies to periodontal bacteria in } \\
\text { serum of AD and normal controls. } \\
\text { Investigation of the use of } \\
\text { biomarkers (TNF } \alpha \text { and antibodies } \\
\text { against periodontal bacteria) for the } \\
\text { diagnosis of AD) }\end{array}$ & $\begin{array}{l}\text { A. actinomycetemcomitans, } \\
\text { T. forsythia, } P \text {. gingivalis (IgG). } \\
\text { TNF- } \alpha, \text { IL- } 1 \beta \text { and IL- } 6 \text { in plasma. } \\
\text { APOE } 4 \varepsilon \text { gene expression. }\end{array}$ & $\begin{array}{l}\text { Higher expression of antibodies to periodontal } \\
\text { bacteria and TNF } \alpha \text { in serum of AD patients than } \\
\text { in controls. } \\
\text { These measures could contribute to the diagnosis } \\
\text { of AD. } \\
\text { No significant difference in cytokine levels } \\
\text { between carriers of APOE } 4 \varepsilon \text { and non-carriers } \\
\text { * Small sample size, study design }\end{array}$ \\
\hline $\begin{array}{l}\text { Syrjälä et al., } 2010 \\
\text { [29] }\end{array}$ & $\begin{array}{l}\text { Case control study } \\
\mathrm{N}=76 / 278\end{array}$ & $\begin{array}{l}\text { Analysis of the association between } \\
\text { diagnosed dementia and oral health } \\
\text { among an elderly population aged } \\
75 \text { years or older. }\end{array}$ & $\begin{array}{l}\text { Diagnosis of dementia as } \\
\text { Alzheimer's disease, vascular } \\
\text { dementia, dementia due to other } \\
\text { general medical (DSM-IV), } \\
\text { dementia with Lewy bodies } \\
\text { (McKeith Criteria). } \\
\text { Number of teeth with dental caries } \\
\text { and with deep periodontal pockets } \\
\text { ( } \geq 4 \mathrm{~mm} \text { ), edentulousness, oral } \\
\text { hygiene index. }\end{array}$ & $\begin{array}{l}\text { Significant probability to have carious teeth, teeth } \\
\text { with deep periodontal pockets and poor oral and } \\
\text { denture hygiene in patient with Alzheimer's } \\
\text { disease and persons with other types of dementia } \\
\text { compared with non-demented persons. } \\
\text { * Study design, sample size, lack of an } \\
\text { assessment of inter-examiner and intra-examiner } \\
\text { reliability of the oral examinations. }\end{array}$ \\
\hline $\begin{array}{l}\text { Poole et al., } 2013 \\
\text { [49] }\end{array}$ & $\begin{array}{l}\text { Case control study } \\
\mathrm{N}=10 / 10\end{array}$ & $\begin{array}{l}\text { Assessment of the presence of the } \\
\text { major periodontal bacteria and/or } \\
\text { their components in the brain tissue } \\
\text { of people with and without } \\
\text { dementia. }\end{array}$ & P. gingivalis, T. denticola, T. forsythia & $\begin{array}{l}\text { Presence of } P \text {. gingivalis- LPS in AD brain with } \\
12 \mathrm{~h} \text { maximum postmortem delay. } \\
\text { No evidence of } P \text {. gingivalis LPS in brain tissue of } \\
\text { non-AD controls with a longer post-mortem time } \\
\text { (up to } 43 \mathrm{~h} \text { ). } \\
\text { * Study design, small sample size. }\end{array}$ \\
\hline
\end{tabular}


Table 1. Cont.

\begin{tabular}{|c|c|c|c|c|}
\hline Reference(s) & Study Design & Objectives & Evaluated Factors & Mains Results and Limitations * \\
\hline $\begin{array}{l}\text { De Souza Rolim et al., } 2014 \\
\text { [28] }\end{array}$ & $\begin{array}{l}\text { Case control study } \\
\mathrm{N}=29 / 30\end{array}$ & $\begin{array}{l}\text { Assessment of mandibular function, } \\
\text { orofacial pain and oral status in } \\
\text { patients with mild AD compared to } \\
\text { age- and sex-matched healthy } \\
\text { subjects. }\end{array}$ & $\begin{array}{l}\text { Temporomandibular disorders } \\
\text { McGill Pain Questionnaire, DMFT } \\
\text { index, } \\
\text { plaque and gingival bleeding } \\
\text { indexes (PI, BI), PPD, } \\
\text { cementoenamel junction (CEJ) and } \\
\text { (CAL) }\end{array}$ & $\begin{array}{l}\text { Significant higher prevalence of orofacial pain, } \\
\text { articular abnormalities in temporomandibular } \\
\text { joints and periodontal infections in AD patients } \\
\text { than in healthy controls. } \\
\text { * Study design, sample size }\end{array}$ \\
\hline $\begin{array}{l}\text { Martande et al., } 2014 \\
\text { [31] }\end{array}$ & $\begin{array}{l}\text { Case control study } \\
\mathrm{N}=58 / 60\end{array}$ & $\begin{array}{l}\text { Comparison of periodontal health } \\
\text { status in people with and without } \\
\text { AD from } 50 \text { to } 80 \text { years }\end{array}$ & $\begin{array}{l}\text { Plaque index (PI), gingival index } \\
\text { (GI), PPD, CAL), percentage } \\
\text { bleeding on probing }(\% \text { BOP). } \\
\text { Degree of cognitive impairment by } \\
\text { Mini-Mental State Examination } \\
\text { (MMSE) }\end{array}$ & $\begin{array}{l}\text { Significant differences in mean GI, PI, PD, CAL, } \\
\text { and \%BOP between different groups (Non AD, } \\
\text { Mild, moderate and severe AD). } \\
\text { Significant elevation of periodontal parameters in } \\
\text { AD patients compared to non-AD patients. } \\
\text { Deterioration of periodontal status with AD } \\
\text { progression } \\
\text { * Study design, sample size, no assessment of } \\
\text { socio-economic status, education, changes in oral } \\
\text { hygiene regimes as dementia progresses, dietary } \\
\text { changes and access to dental care. }\end{array}$ \\
\hline $\begin{array}{l}\text { Noble et al., } 2014 \\
\text { [38] }\end{array}$ & $\begin{array}{l}\text { Case-cohort study } \\
\mathrm{N}=110 / 109\end{array}$ & $\begin{array}{l}\text { Study of the association between } \\
\text { pre-morbid levels of serum IgG } \\
\text { antibodies to selected periodontal } \\
\text { microbiota and risk for incident AD. }\end{array}$ & $\begin{array}{l}\text { P. gingivalis, T. forsythia, } A \text {. } \\
\text { actinomycetemcomitans, T. denticola, C. } \\
\text { rectus, Eubacterium nodatum, } \\
\text { Actinomyces naeslundii (IgG) }\end{array}$ & $\begin{array}{l}\text { The serum concentration of immunoglobulin } \mathrm{G} \\
\text { (IgG) against common periodontal bacteria } \\
\text { represents a risk factor for developing AD. } \\
\text { High concentrations of serum IgG associated to } \\
\text { Actinomyces naeslundii was associated to an } \\
\text { increased risk for developing incident AD. } \\
\text { * Sample size, Possibility of reverse causality due } \\
\text { to the lack of exclusion of patients with mild } \\
\text { cognitive impairment (levels of antibodies to the } \\
\text { periodontal microbiota may have been affected } \\
\text { by cognitive impairment). }\end{array}$ \\
\hline
\end{tabular}


Table 1. Cont.

\begin{tabular}{|c|c|c|c|c|}
\hline Reference(s) & Study Design & Objectives & Evaluated Factors & Mains Results and Limitations* \\
\hline $\begin{array}{l}\text { Kamer et al., } 2015 \\
\text { [15] }\end{array}$ & $\begin{array}{l}\text { Cross sectional study } \\
N=38\end{array}$ & $\begin{array}{l}\text { Evaluation of the association } \\
\text { between periodontal disease burden } \\
\text { with the brain amyloid load in } \\
\text { cognitively normal patients. }\end{array}$ & $\begin{array}{l}\text { CAL, PPD, Bleeding on probing } \\
\text { (BOP). } \\
\text { Amyloid load in AD vulnerable } \\
\text { brain areas (prefrontal cortex, } \\
\text { middle frontal gyrus, lateral } \\
\text { temporal lobe, inferior parietal } \\
\text { lobule, and posterior cingulate } \\
\text { cortex/precuneus) }\end{array}$ & $\begin{array}{l}\text { Significant association between CAL and an } \\
\text { increased amyloid load in vulnerable AD brain } \\
\text { areas after adjusting for confounders (age, ApoE } \\
\text { and smoking). } \\
\text { No significant interaction between ApoE and } \\
\text { periodontal measures. } \\
\text { * Sample size, Limited generalisation of results } \\
\text { due to the homogeneity of the study population, } \\
\text { self-selected patient. }\end{array}$ \\
\hline $\begin{array}{l}\text { Cestari et al., } 2016 \\
\text { [48] }\end{array}$ & $\begin{array}{l}\text { Case control study } \\
N=25 / 19 / 21\end{array}$ & $\begin{array}{l}\text { Investigation of the prevalence of } \\
\text { oral infections and blood levels of } \\
\text { IL- } 1 \beta, T N F-\alpha \text {, and IL- } 6 \text { in patients } \\
\text { with AD, mild cognitive impairment } \\
\text { (MCI), and onn demented controls. }\end{array}$ & $\begin{array}{l}\text { Serum level of IL- } 1 \beta \text {, IL- } 6 \text {, and } \\
\text { TNF- } \alpha \text {. }\end{array}$ & $\begin{array}{l}\text { Patients with AD had significantly higher IL-6 } \\
\text { levels than controls. } \\
\text { Significant association between IL- } 6 \text { and TNF- } \alpha \\
\text { in patients with AD or MCI and periodontitis } \\
\text { * Study design, sample size }\end{array}$ \\
\hline $\begin{array}{l}\text { Ide et al., } 2016 \\
\text { [19] }\end{array}$ & $\begin{array}{l}\text { Observational cohort study } \\
N=60\end{array}$ & $\begin{array}{l}\text { Evaluation of the effects of } \\
\text { periodontitis in patients with } \\
\text { Alzheimer's disease over a } \\
\text { six-month follow-up. }\end{array}$ & $\begin{array}{l}\text { P. gingivalis antibodies } \\
\text { CRP, TNF } \alpha \text {, IL } 10 \\
\text { Cognitive scores (sMMSE and } \\
\text { ADAS-COG) }\end{array}$ & $\begin{array}{l}\text { No significant relationship between serum } \\
\text { baseline P. gingivalis antibody levels and rates of } \\
\text { cognitive decline. } \\
P \text {. gingivalis antibody levels were associated with } \\
\text { a fall in serum IL10 levels and an increase in } \\
\text { serum TNF } \alpha \text { levels over a six month follow up. } \\
\text { * Small sample size and short term follow up }\end{array}$ \\
\hline $\begin{array}{l}\text { Chen et al., } 2017 \\
\text { [33] }\end{array}$ & $\begin{array}{l}\text { Retrospective cohort study } \\
\mathrm{N}=27963\end{array}$ & $\begin{array}{l}\text { Assessment of the risk of } \\
\text { developing AD in patients with } \\
\text { chronic periodontitis. }\end{array}$ & $\begin{array}{l}\text { Chronic periodontitis and AD } \\
\text { diagnosis (ICM 9). }\end{array}$ & $\begin{array}{l}\text { No significant higher risk of developing AD in } \\
\text { Patients with } 1 \text { year of } C P \text { exposure than those } \\
\text { without } C P \text {. } \\
\text { Significant higher risk of developing AD in } \\
\text { Patients with } 10 \text { years of CP exposure than those } \\
\text { without CP. } \\
\text { Higher prevalence of hyperlipidaemia, } \\
\text { depression, traumatic brain injury and } \\
\text { co-morbiditiess in patients with CP had a than } \\
\text { those in the unexposed cohort. } \\
\text { * Possible underestimation of the incidence of CP } \\
\text { or AD, No data regarding the severity of AD and } \\
\text { education level. }\end{array}$ \\
\hline
\end{tabular}


Table 1. Cont.

\begin{tabular}{|c|c|c|c|c|}
\hline Reference(s) & Study Design & Objectives & Evaluated Factors & Mains Results and Limitations * \\
\hline $\begin{array}{l}\text { Holmer et al., } 2018 \\
\text { [30] }\end{array}$ & $\begin{array}{l}\text { Case control study } \\
\mathrm{N}=154 / 76\end{array}$ & $\begin{array}{l}\text { Assessment of the possible increase } \\
\text { risk of mild cognitive impairment } \\
\text { (MCI), subjective cognitive decline } \\
\text { (SCD) and Alzheimer's disease (AD) } \\
\text { associated with periodontal disease. } \\
\text { Investigation of the potential } \\
\text { associations between common } \\
\text { biofilm-induced dental diseases } \\
\text { (dental caries and endodonticula), } \\
\text { their sequelae (tooth loss) and } \\
\text { cognitive impairment. }\end{array}$ & $\begin{array}{l}\text { Periodontal status (oral hygiene, } \\
\text { PPD, bleeding on pocket probing } \\
\text { (BoP), suppuration, tooth mobility } \\
\text { furcation involvment, marginal } \\
\text { alveolar bone loss (MABL). } \\
\text { Number of teeth, dental implants } \\
\text { present, and dental caries. }\end{array}$ & $\begin{array}{l}\text { Generalized marginal alveolar bone loss is } \\
\text { associated with early cognitive impairment and } \\
\text { AD. } \\
\text { Poor oral health was more prevalent among cases } \\
\text { than among healthy controls. } \\
\text { * Study design, sample size, possible temporal } \\
\text { bias with reverse causality (reduced cognitive } \\
\text { function leads to poor oral health), no APOE } \\
\text { genotyping }\end{array}$ \\
\hline $\begin{array}{l}\text { Ilievski et al., } 2018 \\
\text { [37] }\end{array}$ & $\begin{array}{l}\begin{array}{l}\text { Experimental study } \\
\text { (mice) } \\
\mathrm{N}=20\end{array}\end{array}$ & $\begin{array}{l}\text { Assessment of the } \\
\text { neuropathological effects } \\
\text { (production of extracellular A } \beta 42 \\
\text { and neurofibrillary tangles) of } \\
\text { repeated chronic exposure to a } \\
\text { periodontal pathogen. }\end{array}$ & $\begin{array}{l}\text { P. gingivalis/Gingipain } \\
\text { TNF } \alpha \text {, IL1 } \beta \text {, and IL6 } \\
\text { Alzheimer's disease-related genes } \\
\text { expression (APP, BACE 1, PSEN1, } \\
\text { ADAM10) }\end{array}$ & $\begin{array}{l}\text { P. gingivalis /gingipain were detected in the } \\
\text { hippocampus of mice infected with Pg. } \\
\text { Significantly higher expression of the } \\
\text { proinflammatory cytokine IL1 } \beta \text {, IL } 6 \text { and TNF } \alpha \text { in } \\
\text { the hippocampus of experimental mice than } \\
\text { controls. } \\
\text { Significant increase in the expression of APP and } \\
\text { BACE1 in the experimental group compared to } \\
\text { the control group. } \\
\text { Significant decrease in the expression of } \\
\text { ADAM10 in the experimental group compared to } \\
\text { the control group. } \\
\text { Detection of Phospho-Tau protein in the } \\
\text { experimental but not in the control mice } \\
\text { * No direct or indirect mechanisms to explain } \\
\text { these changes could be identified. }\end{array}$ \\
\hline $\begin{array}{l}\text { Laugisch et al., } 2018 \\
\text { [50] }\end{array}$ & $\begin{array}{l}\text { Case control study } \\
\mathrm{N}=20 / 20\end{array}$ & $\begin{array}{l}\text { Verification of the presence of } \\
\text { periodontal pathogens and the } \\
\text { intrathecal generation of } \\
\text { pathogen-specific antibodies in } \\
\text { patients with AD and with other } \\
\text { forms of dementia (DEM-noAD). }\end{array}$ & $\begin{array}{l}\text { Antibody levels against } A \text {. } \\
\text { actinomycetemcomitans, T. denticola, } T \text {. } \\
\text { forsythia, } \\
P \text {. gingivalis in CSF and serum } \\
\text { Total tau protein (T-tau) and } \\
\text { amyloid- } \beta \text { (A } \beta 1-42) \text { in CSF. } \\
\text { Monocyte chemoattractant protein-1 } \\
\text { (MCP-1/CCL2) }\end{array}$ & $\begin{array}{l}\text { Periodontal pathogens may enter the brain and } \\
\text { stimulate a local immune response. } \\
\text { Significant association between T-tau levels in the } \\
\text { AD group and serum levels of anti-P. gingivalis } \\
\text { antibodies and MCP-1/CCL-2. } \\
\text { * Sample size }\end{array}$ \\
\hline
\end{tabular}


Table 1. Cont.

\begin{tabular}{|c|c|c|c|c|}
\hline Reference(s) & Study Design & Objectives & Evaluated Factors & Mains Results and Limitations* \\
\hline $\begin{array}{l}\text { Maurer et al., } 2018 \\
\text { [35] }\end{array}$ & $\begin{array}{l}\text { Case control study } \\
\mathrm{N}=20 / 20\end{array}$ & $\begin{array}{l}\text { Evaluation of the possible link } \\
\text { between Alzheimer's dementia and } \\
\text { bacterial infestation of the oral } \\
\text { cavity. }\end{array}$ & $\begin{array}{l}\text { A. actinomycetemcomitans, } P . \\
\text { gingivalis, F. nucleatum }\end{array}$ & $\begin{array}{l}\text { AD-patients showed higher bacterial load in } \\
\text { dental plaque compared to controls. } \\
\text { * Study design, sample size }\end{array}$ \\
\hline $\begin{array}{l}\text { Choi et al., } 2019 \\
\text { [21] }\end{array}$ & $\begin{array}{l}\text { Retrospective cohort study } \\
\mathrm{N}=262349\end{array}$ & $\begin{array}{l}\text { Determination of the association } \\
\text { between chronic periodontitis (CP), } \\
\text { AD and vascular dementia (VD) } \\
\text { from the Korean National Health } \\
\text { Insurance Service (NHIS) database, } \\
\text { using a several covariates (smoking, } \\
\text { alcohol consumption and physical } \\
\text { activity). }\end{array}$ & $\begin{array}{l}\text { CP diagnosis (CD-10 code K05.3) } \\
\text { associated with at least one of the } \\
\text { CP-related treatments. } \\
\text { Prescription of dementia-related } \\
\text { drugs as part of a diagnosis of AD } \\
\text { (ICD-10 codes F00, G30) or VD } \\
\text { (ICD-10 code F01) } \\
\text { Age, sex, household income, } \\
\text { smoking status, alcohol } \\
\text { consumption, physical activity, } \\
\text { body mass index, systolic blood } \\
\text { pressure, fasting serum glucose, } \\
\text { total cholesterol and Charlson } \\
\text { Comorbidity Index }\end{array}$ & $\begin{array}{l}\text { Chronic periodontitis patients had elevated risk } \\
\text { for overall dementia (aHR = } 1.06 \text {; } \\
95 \% \mathrm{CI}=1.01-1.11, p=0.042) \text { and } \mathrm{AD} \\
\text { (aHR }=1.05 ; 95 \% \mathrm{CI}=1.00-1.11, p=0.042) \text { than } \\
\text { non-chronic periodontitis participants. } \\
\text { * Study design, Information on CP-related clinical } \\
\text { index limited, definition of dementia based on } \\
\text { drug reimbursement, no evaluation of level of } \\
\text { education or apolipoprotein E (APOE) e4 } \\
\text { genotype. }\end{array}$ \\
\hline $\begin{array}{l}\text { Dominy et al., } 2019 \\
\text { [39] }\end{array}$ & $\begin{array}{l}\text { Experimental study } \\
\text { (mice) } \\
\mathrm{N}=140\end{array}$ & $\begin{array}{l}\text { Assessment of the prevalence of } P \text {. } \\
\text { gingivalis }(\mathrm{Pg}) \text { in the brains of people } \\
\text { with Alzheimer's disease and } \\
\text { possible Pg-dependent mechanisms } \\
\text { of action in neurodegeneration and } \\
\text { Alzheimer's pathology. }\end{array}$ & $\begin{array}{l}\text { P. gingivalis and Gingipaïn load in } \\
\text { brain tissue }\end{array}$ & $\begin{array}{l}\text { P. gingivalis and gingipains load in the brain play } \\
\text { a significative role in the pathogenesis of AD. } \\
\text { Reduction in } P \text {. gingivalis brain bacterial load and } \\
\text { neuroinflammation as well as a blockage of } A \beta \\
1-42 \text { peptide production were obtained by } \\
\text { gingipain inhibition. } \\
\text { * Study design, sample size }\end{array}$ \\
\hline $\begin{array}{l}\text { Hayashi et al., } 2019 \\
\text { [43] }\end{array}$ & $\begin{array}{l}\text { Experimental study } \\
\text { (Mice) } \\
\mathrm{N}=80\end{array}$ & $\begin{array}{l}\text { Evaluation of the effects of brain } \\
\text { exposure to Porphyromonas } \\
\text { gingivalis-derived } \\
\text { lipopolysaccharide (Pg-LPS) on } \\
\text { cognitive impairment and organ } \\
\text { dysfunction in an AD mouse model. }\end{array}$ & $\begin{array}{l}\text { P. gingivalis LPS } \\
\text { Morris water maze tests }\end{array}$ & $\begin{array}{l}\text { No cognitive impairment could be associated } \\
\text { with acute or continuous brain exposure to } \\
\text { Pg-LPS. } \\
\text { Continuous brain exposure to Pg-LPS triggered } \\
\text { sarcopenia and heart damage in AD model mice. } \\
\text { * Study design }\end{array}$ \\
\hline
\end{tabular}


Table 1. Cont.

\begin{tabular}{|c|c|c|c|c|}
\hline Reference(s) & Study Design & Objectives & Evaluated Factors & Mains Results and Limitations * \\
\hline $\begin{array}{l}\text { Liu et al., } 2019 \\
\text { [34] }\end{array}$ & $\begin{array}{l}\text { Case control study } \\
\mathrm{N}=39 / 39\end{array}$ & $\begin{array}{l}\text { Identification of differences in oral } \\
\text { bacterial community composition } \\
\text { between AD patients and healthy } \\
\text { patients. } \\
\text { Evaluation of the association } \\
\text { between oral bacteria and AD } \\
\text { severity } \\
\text { Evaluation of differences in oral } \\
\text { bacterial flora according to APOE } \varepsilon 4 \\
\text { expression. }\end{array}$ & $\begin{array}{l}\text { Alpha and beta diversity of salivary } \\
\text { microbiota } \\
\text { APOE } \varepsilon 4 \text { expression }\end{array}$ & $\begin{array}{l}\text { Significant decrease of richness and diversity of } \\
\text { salivary microbiota in patients with Alzheimer's } \\
\text { disease than in healthy controls. } \\
\text { No bacteria associated with the severity of AD. } \\
\text { Significant decrease in Actinobacillus and } \\
\text { Actinomyces levels in patients with APOE } \varepsilon 4 \\
\text { Abundance of Abiotrophia and } \\
\text { Desulfomicrobium levels in patients with APOE } \\
\varepsilon 4(+) \\
\text { * Small sample size, no collection of dental } \\
\text { plaque bacteria }\end{array}$ \\
\hline $\begin{array}{l}\text { Beydoun et al., } 2020 \\
\text { [32] }\end{array}$ & $\begin{array}{l}\text { Retrospective cohort study } \\
N=6650\end{array}$ & $\begin{array}{l}\text { Evaluation of the association of } \\
\text { immune response (IgG) to } \\
\text { periodontal pathogens with the } \\
\text { incidence of dementia and AD } \\
\text { mortality in middle-aged ( }>45 \text { years) } \\
\text { and elderly ( }>65 \text { years) US adults. }\end{array}$ & $\begin{array}{l}\text { Periodontal pathogens } \\
\text { Immunoglobulin G (IgG): } \\
\text { A. actinomycetemcomitans, } P \text {. } \\
\text { gingivalis, T. forsythia, T. denticola, C. } \\
\text { rectus, Eubacterium nodatum, P. } \\
\text { intermedia, Prevotella nigrescens, } \\
\text { Prevotella melaninogenica, F. } \\
\text { nucleatum, Parvimonas micra, } \\
\text { Selenomonas noxia, Eikenella corrodens, } \\
\text { Capnocylophaga ochracea, } \\
\text { Streptococcus intermedius, } \\
\text { Streptococcus oralis, Streptococcus } \\
\text { mutans, Vellonella Parvula, } \\
\text { Actinomyces naeslundii. } \\
\text { AD Mortality and Incidence Status. } \\
\text { Clinical Attachment loss (CAL) and } \\
\text { probing pocket depth (PPD) }\end{array}$ & $\begin{array}{l}\text { AD incidence was linked to a composite of } C \text {. } \\
\text { rectus and } P \text {. gingivalis. } \\
\text { AD mortality risk was increased with composite } \\
\text { loading highly on IgG for } P \text {. gingivalis, } P \text {. } \\
\text { intermedia, Prevotella nigrescens, F. nucleatum, C. } \\
\text { rectus, Streptococcus intermedius, Capnocylophaga } \\
\text { Ochracea, and } P \text {. melaninogenica. } \\
\text { Only a marginal association between incident } \\
\text { AD risk and PPD was detected among men and } \\
\text { older individuals } \\
\text { * Study design }\end{array}$ \\
\hline
\end{tabular}


Table 1. Cont

\begin{tabular}{|c|c|c|c|c|}
\hline Reference(s) & Study Design & Objectives & Evaluated Factors & Mains Results and Limitations * \\
\hline $\begin{array}{l}\text { De Oliveira Araújo et al., } \\
2021 \\
{[27]}\end{array}$ & $\begin{array}{l}\text { Case control study } \\
\mathrm{N}=50 / 52\end{array}$ & $\begin{array}{l}\text { Test the association between } \\
\text { periodontitis and AD. } \\
\text { Assessment of the possible negative } \\
\text { impact of periodontal status on } \\
\text { perceived oral health-related quality } \\
\text { of life (OHRQoL) }\end{array}$ & $\begin{array}{l}\mathrm{PPD} \geq 5 \mathrm{~mm} \text {, and CAL } \geq 5 \mathrm{~mm} \\
\text { Geriatric Oral Health Assessment } \\
\text { Index (GOHAI) questionnaire. } \\
\text { Socio-demographic data. }\end{array}$ & $\begin{array}{l}\text { AD patients had fewer teeth, greater and a } \\
\text { superior percentage of sites with plaque, calculus, } \\
\text { and bleeding on probing than healthy controls. } \\
\text { Significant association between periodontitis and } \\
\text { AD after adjusting for age, gender, income and } \\
\text { education. } \\
\text { Periodontitis is associated with AD, but not with } \\
\text { patients' OHRQoL } \\
\text { * Study design, sample size }\end{array}$ \\
\hline $\begin{array}{l}\text { Díaz-Zúñiga et al., } 2020 \\
\text { [42] }\end{array}$ & $\begin{array}{l}\text { Experimental study } \\
\text { (Rats) } \\
\mathrm{N}=30\end{array}$ & $\begin{array}{l}\text { Evaluation of the effects of short } \\
\text { exposure to encapsulated strains of } \\
P . \text { gingivalis on AD brain markers, } \\
\text { neuroinflammation and cognitive } \\
\text { decline in young rats. }\end{array}$ & $\begin{array}{l}\text { P. gingivalis K1, K2, or K4 serotypes } \\
\text { and the K1-isogenic } \\
\text { non-encapsulated mutant (GPA). } \\
\text { Oasis maze task. } \\
\text { Cytokines (IL-1b, IL-4, IL-6, IL-10, } \\
\text { TNF- } \alpha \text {, IFN- } \gamma \text { ). } \\
\text { A } \beta 1-42 \text { peptide and tau } \\
\text { phosphorylation levels in } \\
\text { hippocampus. }\end{array}$ & $\begin{array}{l}\text { Significant increase of pro-inflammatory } \\
\text { cytokines (IL-1b, IL-6, TNF-a, IFN- } \gamma \text { ) in the } \\
\text { hippocampus of rats infected with P. gingivalis } \\
\text { encapsulated serotypes K1 and K2. } \\
\text { None of these effects were observed in rats } \\
\text { infected with the non-encapsulated bacterial } \\
\text { strains. } \\
\text { K1 or K2 P. gingivalis-infected rats displayed } \\
\text { memory deficits, increased A } \beta 1-42 \text { levels, and } \\
\text { Tau hyperphosphorylation in the hippocampus } \\
\text { * Sample size, study design }\end{array}$ \\
\hline
\end{tabular}


Table 1. Cont.

\begin{tabular}{|c|c|c|c|c|}
\hline Reference(s) & Study Design & Objectives & Evaluated Factors & Mains Results and Limitations * \\
\hline $\begin{array}{l}\text { Kantarci et al., } 2020 \\
\text { [26] }\end{array}$ & $\begin{array}{l}\text { Experimental study (Mice) } \\
\mathrm{N}=30\end{array}$ & $\begin{array}{l}\text { Evaluation of the impact of } \\
\text { experimentally induced periodontal } \\
\text { disease in a mouse model of AD on } \\
\text { the inflammatory process in the } \\
\text { brain and microglia function. }\end{array}$ & $\begin{array}{l}\text { Alveolar bone loss } \\
\text { Insoluble A } \beta 40 \text { and A } \beta 442 \text { peptide. } \\
\text { Microglial markers in brain (Iba1). } \\
\text { Cytokine and Chemokine in CSF } \\
\text { (GM-CSF, IFN- } \gamma \text {, IL-1 } \beta, \text { IL-6, IL-10, } \\
\text { TNF- } \alpha, \text { MCP 1). }\end{array}$ & $\begin{array}{l}\text { Periodontal disease increases bone loss in } \\
\text { AD-modelled (5xFAD) and control wild-type } \\
\text { (WT) mice. Alveolar bone loss is higher in 5xFAD } \\
\text { than in WT at baseline. } \\
\text { No significant difference in alveolar bone loss } \\
\text { after the induction of experimental PD between } \\
5 x F A D \text { and WT mice } \\
\text { The mean level of insoluble A } \beta 42, \text { but not A } \beta 40 \text {, } \\
\text { was significantly higher in 5xFAD mice with } \\
\text { induced PD than in 5xFAD mice without induced } \\
\text { PD. } \\
\text { Decline in microglial markers (Iba1 )in the } \\
\text { proximity of A } \beta \text { plaques in 5xFAD mice with } \\
\text { periodontal disease compared to those without } \\
\text { periodontal disease. } \\
\text { Induced periodontal disease reduced IL-10 in } \\
5 x F A D \text { mice. } \\
\text { Higher unresolved inflammation in the brain of } \\
5 x F A D \text { mice before and after induction of } \\
\text { periodontal disease compared to WT controls } \\
\text { based on the ratio of TNF- } \alpha \text { to IL-10. } \\
\text { * Study design, Sample size, no characterization } \\
\text { of the bacterial flora }\end{array}$ \\
\hline $\begin{array}{l}\text { Leblhuber et al., } 2020 \\
\text { [44] }\end{array}$ & $\begin{array}{l}\text { Cross sectional } \\
\text { study } \\
\mathrm{N}=20\end{array}$ & $\begin{array}{l}\text { Evaluation of the effects of chronic } \\
\text { low-grade immune activation by } \\
\text { salivary periodontopathogen } \\
\text { bacteria in AD patients }\end{array}$ & $\begin{array}{l}\text { A. actinomycetemcomitans, T. denticola, } \\
\text { T. forsythia, } \\
\text { P. gingivalis, P. intermedia in salivary. } \\
\text { MMSE and CDT. } \\
\text { Serum concentrations of neopterin } \\
\text { and of tryptophan. }\end{array}$ & $\begin{array}{l}\text { Significant association between the salivary } \\
\text { presence of } P \text {. gingivalis and lower MMSE and } \\
\text { lower tendency to CDT. } \\
\text { Significant lower neopterin concentrations } \\
\text { associated with the presence of } T \text {. denticola in AD } \\
\text { patient saliva. } \\
\text { Significant lower kynurenine concentrations } \\
\text { associated with the presence of } T \text {. forsythia in AD } \\
\text { patient saliva. } \\
\text { * Sample size, study design, no evaluation of the } \\
\text { ApoE status }\end{array}$ \\
\hline
\end{tabular}


Table 1. Cont.

\begin{tabular}{|c|c|c|c|c|}
\hline Reference(s) & Study Design & Objectives & Evaluated Factors & Mains Results and Limitations * \\
\hline $\begin{array}{l}\text { Sun et al., } 2020 \\
\text { [53] }\end{array}$ & $\begin{array}{l}\text { A bidirectional Mendelian } \\
\text { randomization study } \\
\mathrm{N}=4924 / 7301\end{array}$ & $\begin{array}{l}\text { Examination of the potential causal } \\
\text { relationship between AD and } \\
\text { chronic periodontitis bidirectionally } \\
\text { in the population of European } \\
\text { ancestry. }\end{array}$ & $\begin{array}{l}\text { Single-nucleotide polymorphisms } \\
\text { associated with periodontitis and } \\
\text { AD. }\end{array}$ & $\begin{array}{l}\text { No evidence for a bidirectional genetic } \\
\text { relationship between AD and periodontitis from } \\
\text { analysis of Genome-Wide Association Studies } \\
\text { data. } \\
{ }^{*} \text { Mendelian randomisation does not assess the } \\
\text { impact of the duration of periodontal disease on } \\
\text { the risk of developing AD, The genetic tool used } \\
\text { to define PD may not be suitable for detecting the } \\
\text { causal link between PD and AD. }\end{array}$ \\
\hline $\begin{array}{l}\text { Yamada et al., } 2020 \\
\text { [40] }\end{array}$ & $\begin{array}{l}\text { In vitro study } \\
\text { (cells) }\end{array}$ & $\begin{array}{l}\text { Evaluation of the influence of } \\
\text { phosphoglycérol dihydrocéramide } \\
\text { (PGDHC) produced by P. gingivalis } \\
\text { on hallmark findings in AD. }\end{array}$ & $\begin{array}{l}\text { Concentrations of PGDHC, A } \beta \\
\text { peptide, Protein Tau and } \\
\text { senescence-associated secretory } \\
\text { phenotype ( } \beta \text {-galactosidase, } \\
\text { cathepsin B, cysteine, TNF- } \alpha \text { and } \\
\text { IL-6 pro-inflammatory cytokines) }\end{array}$ & $\begin{array}{l}\text { Exposure to PGDHC, but not to Pg-LPS, } \\
\text { significantly enhances secretion of A } \beta \text { peptide in } \\
\text { a dose-dependent manner from CHO-7WD101 } \\
\text { cells in vitro }{ }^{1} \text {. } \\
\text { PGDHC also significantly Induces the } \\
\text { Site-Specific Phosphorylation of protein Tau in a } \\
\text { dose-dependent manner in SH-SY5Y2 cells } \\
\text { compared to the control cells. } \\
\text { PGDHC or Pg-LPS elevated expression of } \\
\beta \text {-galactosidase, cathepsin B, cysteine, TNF- } \alpha \\
\text { and IL-6 pro-inflammatory cytokines in SH-SY5Y } \\
\text { cells. } \\
{ }^{*} \text { In vitro study }\end{array}$ \\
\hline
\end{tabular}


Table 1. Cont.

\begin{tabular}{|c|c|c|c|c|}
\hline Reference(s) & Study Design & Objectives & Evaluated Factors & Mains Results and Limitations * \\
\hline $\begin{array}{l}\text { Zhang et al., } 2020 \\
\text { [41] }\end{array}$ & $\begin{array}{l}\text { Experimental study (Rats) } \\
\mathrm{N}=24\end{array}$ & $\begin{array}{l}\text { Examination of the association } \\
\text { between oral health and cognition } \\
\text { in humans and rats. }\end{array}$ & $\begin{array}{l}\text { Morris Water Maze test } \\
\text { Concentrations of A } \beta 1-40 \text { peptide, } \\
\text { TNF- } \alpha, \text { IL-1, IL- } 6 \text { and CRP in the } \\
\text { hippocampus and the cerebral } \\
\text { cortex }\end{array}$ & $\begin{array}{l}\text { No significant differences in the Morris Water } \\
\text { Maze test between AD rats and AD rats with } \\
\text { induced periodontitis. } \\
\text { Significant elevation of A } \beta 1-40 \text { concentration in } \\
\text { the cerebral cortex in AD rats with periodontitis } \\
\text { than in AD rats. } \\
\text { TNF- } \alpha \text { levels in the hippocampus of the AD with } \\
\text { periodontitis group were significantly higher } \\
\text { than those of the AD and the control group } \\
\text { IL-1 levels in the cerebral cortex of the AD with } \\
\text { periodontitis group were significantly higher } \\
\text { than those of the AD group and the control group. } \\
\text { IL-6 levels in the hippocampus and the cerebral } \\
\text { cortex of the AD with periodontitis groups were } \\
\text { significantly higher than those of the AD and the } \\
\text { control group. } \\
\text { * Study design, sample size, no detection of } \\
\text { periodontal pathogens in the brain. }\end{array}$ \\
\hline
\end{tabular}

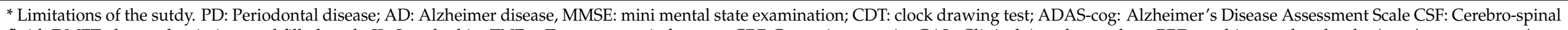

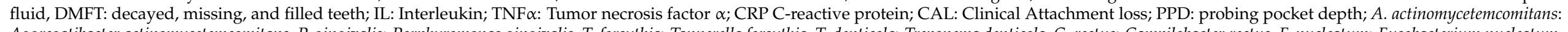

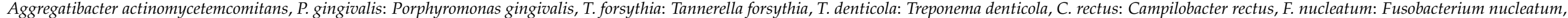

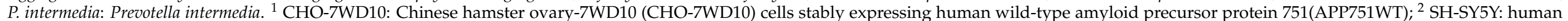
neuroblastoma cells. 


\section{Discussion}

\subsection{Oral Microbiome and Alzheimer's Disease}

The bidirectional relationship between the gut microbiome and AD is increasingly well-understood, leading to the definition of the gut-brain axis [55]. The detection of peptides in the gut and brain helped to lay the foundation for the concept of the gut-brain axis in the sixties and seventies [56]. Similar studies argue for a relationship between the oral microbiome and AD. Thus, the particular dysbiotic signature in Alzheimer's patients involving periodontal bacteria (A. actinomycetemcomitans, P. gingivalis, T. denticola, F. nucleatum) suggests a modulation of oral bacterial flora by the central nervous system as observed for intestinal flora [57]. This finding must be moderated, due to additional factors affecting the oral microbiome of AD patients. Poor oral hygiene from reduced cognition and dexterity, age-related xerostomia, and medication can contribute to oral dysbiosis in these patients [58].

The presence of $P$. gingivalis in the brain, as well as an increase in A $\beta$ peptide secretion, induced by associated compounds (gingipain, phosphoglycerol dihydroceramide), can be related to the antimicrobial activity of $A \beta$ peptide, as demonstrated by Soscia et al. against several Gram-negative and Gram-positive bacteria (Esherichia coli, Streptococcus pneumonia, Streptococcus salivarius) as well as Candida albicans [59]. Long-term colonization by pathogenic bacteria and failure to clear the $\mathrm{A} \beta$ peptides, which was produced in response, can lead to excessive accumulation followed by brain tissue destruction through the formation of amyloid plaques and hyperphosphorylation of the tau protein [60]. These observations can be related to the survey results by Beydoun et al. [32], identifying a correlation between periodontal bacterial communities and the incidence or mortality of AD. In this context, while the evidence for the impact of the microbiome on cognitive performance seems well established [61], the results available in this review regarding the involvement of the oral microbiome on cognitive decline in AD patients seems contradictory.

\subsection{Possible Mechanisms of the Relationship between the Oral Microbiome and Alzheimer's Disease}

Neuroinflammation is an important process in the neurodegeneration associated with AD. It exacerbates key features of the disease, including the deposition of $A \beta$ peptides and hyperphosphorylation of tau. It places this process in a vicious cycle of inflammation and cellular destruction [62]. Thus, the presence in the brain of lipopolysaccharides from T. denticola, T. forsythia, and P. gingivalis that can be associated with increased expression of major proinflammatory cytokines (IL-1 $\beta$, IL- 6 , TNF $\alpha$, and IFN $\gamma$ ) and decreased antiinflammatory cytokines (IL-10) suggests an involvement of the oral microbiota in the occurrence and progression of AD. Furthermore, these periodontal pathogens seem to modulate the immune response in AD patients. This modulation may be related to an alteration of microglial activity associated with an increased risk of AD [63]. However, localized transient inflammation is the normal immunological response of our immune system to cell/tissue damage, and is very important for tissue regeneration and repair [64]. Inflammation is a violent cell self-destructive way of clearing damaged cells. By destroying the infected tissues, the pathogens are cleared as well, and thus almost all microbial infections are self-limiting $[65,66]$. If at the same time the debris of the destroyed cells can be effectively cleaned away by our immune system [67], for example through autophagy, tissue regeneration will be followed, and infection-induced tissue damage will be transient and not become chronic, the patient can easily recover from such transient tissue damage.

While several mechanisms involving nervous, endocrine, and immune signals were advanced in the context of the gut-brain axis [57], no study identified mechanisms of the interaction between oral bacteria and AD. Nevertheless, Rivière et al. proposed the hypothesis that oral bacteria may infect the brain via branches of the trigeminal nerve [36]. The possibility of oral bacteria accessing the bloodstream [68] is a risk for sepsis [69,70] and may be associated more rarely with meningitis when these bacteria translocate to the brain $[71,72]$. It can be assumed that their interactions with the blood-brain barrier may 
also alter its integrity, allowing metabolic products produced by the microbiome, such as short-chain fatty acids, to cross the BBB and then affect brain function, such as the proposed in the gut-brain axis [73]. Although alterations in the BBB have been found both in AD patients and in animal models, their role in the disease process remains unclear [74].

The reciprocal modulation of the expression of some genes involved in $\mathrm{AD}$ and the modulation of oral microbiota has been identified $(34,37)$. It provides the basis for the hypothesis of a plausible common genetic cause for oral dysbiosis and AD. However, according to Sun et al. [53], this hypothesis must be balanced due to the lack of evidence for a bidirectional genetic relationship between $\mathrm{AD}$ and periodontitis. The oral microbiome and associated dysbiosis appear to be only one environmental risk factor for the expression of genes associated with $\mathrm{AD}$, as is the case for diseases such as diabetes or cardiovascular disease, etc. [75].

\subsection{Inflammation, Overnutrition and Lipotoxicity}

Although the virulence of the microorganism determines the damages made by the microorganisms to the host cells before they are cleared by host immunity, this microbial virulence alone does not account for the virulence of disease [66,76]. Most of the virulence of an infectious or chronic non-infectious disease is the result of the overactive inflammation response of our immune system [66,76], which turns local transient inflammation into systemic or chronic inflammation. The driving force for such an inflammatory transition is overnutrition. This is because, when there is overnutrition, the debris of the destroyed cells cannot be effectively cleaned, then this debris will become the nutrition source for bacteria proliferation. This debris can also be turned into lipid intermediates, and induce lipotoxicity. The human immune system also has a pivotal role in nutrition acquisition from the pathogen or the commensal microbiota like bacteria and the damaged tissues [77], and uses them for tissue regeneration if these nutrients just meet the need of tissue regeneration without surplus.

But if there is overnutrition, lipotoxicity as a result of overnutrition will prevent the tissue healing process from happening. Moreover, in the state of over-nutrition, the nutrition generated from the degradation of microbial-infected tissues will make this overnutrition situation worse, lipotoxicity and tissue damage will form a vicious positive feedback loop (as lipotoxicity is also a strong stimulus for cell dysfunction and cell death), which are escalated by the inflammation response, shifting inflammation from local to systemic, creating collateral damage to all other organs including the central nervous system, and may cause AD. So overnutrition could be a more possible linking factor between microbiota (oral or gastrointestinal) and AD.

\subsection{Oral Microbiota Modulation and Alzheimer's Disease Therapy}

Treatments for $\mathrm{AD}$ are currently symptomatic, but research is targeting its pathological features, including $A \beta$ peptides and tau protein [78]. In this context, the probable impact of the oral microbiome on the development of AD opens the door to a complementary therapeutic approach. Only the study by Dominy et al. (2019) is in line with this research by showing the interest in gingipain inhibitors in AD [39]. However, phototherapy, as well as prebiotic compounds and probiotic strains for a global/targeted modulation of the oral microbiome, represent areas of research for the prevention and treatment of AD. Indeed, the results of these potential new methods seem to demonstrate the effectiveness in the modification of the ecosystem of dental plaque by reducing the importance of the periodontal bacteria, which appear to be associated with AD (P. gingivalis, F. nucleatum, C. rectus, and others) $[79,80]$. Blue light is painless, fast, without drug toxicity or effect on taste, and is selective in effect. Its use could help to reduce oral dysbiosis linked to PD [81] and its impacts on AD patients. Probiotic strains affecting the periodontogenic flora through various galenic forms, such as milk drinks, yoghurts, and mouthwash could facilitate oral hygiene measures in $\mathrm{AD}$ patients [82]. 
Modulation of several pathological events in AD such as reduction in amyloid- $\beta$ aggregation and inflammation, regulation of mitochondrial dynamics and increased availability of neuronal energy seem to be associated with different metabolic pathways (e.g., Wnt signalling, 5'-adenosine monophosphate-activated protein kinase) [83]. As Gram-negative bacteria-associated LPS and microbiome-generated amyloids potentially contribute to the regulation of these signalling pathways $[84,85]$, therapeutic strategies to modulate oral dysbiosis as well as to modify bacterially produced amyloids or reduce their production also represent a future focus of research for the treatment of AD.

\section{Limitations and Perspectives}

While the relationship between the oral microbiome and mental disorders is a topic of growing interest, some limitations in the studies in this review must be noted. Thus, in the context of the evaluation of brain colonization by oral bacteria, some authors point to a risk of tissue contamination by the oral microbiota post-mortem [36]. Moreover, despite the microbiome changes over the life course [86], studies are predominantly based on case-control surveys and relatively small samples that do not allow assessment of the impact of exposure duration on the risk of developing AD. The promotion of longitudinal studies is essential to understand the role of the oral microbiome in the incidence and progression of $\mathrm{AD}$.

The decline in cognitive function in $\mathrm{AD}$ patients is linked to behavioural changes that affect oral health. The progressive decline in patients' ability and interest in both performing brushing and complementary oral care leads to the rapid development of oral pathology and dysbiosis [87]. In addition to difficulties in dental self-care, access to professional dental care procedures is complicated by a progressive cognitive decline in $\mathrm{AD}$ patients [88]. Faced with the challenge of an aging population and the increase in the weight of associated AD [89], it appears important to develop research towards solutions that promote the maintenance of the oral flora balance and to raise awareness among health professionals on the prevention of oral dysbiosis.

In addition, with genetic tools and molecular analyses available to identify individual bacteria and their metabolic products, it is possible to locate and track these bacteria in different host tissues to understand which cells they may affect and which metabolic signaling pathways they may activate and thus better understand how AD may be influenced by the oral microbiome. Due to the complexity of the etiopathology of $\mathrm{AD}$ and the interrelation between the factors responsible for the symptoms of the disease, a new therapeutic approach combining different targets is essential to develop new, more effective and personalized interventions and strategies for patients with this disease [90].

\section{Conclusions}

Several studies show a statistical link between AD and oral microbiota. Although the robustness of this link must be confirmed due to numerous confounding factors, evidence is accumulating towards the impact of the oral microbiome in pathophysiological and immuno-inflammatory mechanisms of this disease. The impact of the oral microbiome on the development of AD opens up complementary therapies, such as phototherapy, prebiotic compounds, and probiotic strains for a global or targeted modulation of the oral microbiome, with a favourable influence on the evolution of this pathology.

Author Contributions: Conceptualization, Y.M. and F.D.; Methodology, F.D., Y.M. and G.A.; Resources, F.D. and G.A.; Data curation, Y.M.; Writing-Original Draft Preparation, F.D., Y.M. and G.A.; Writing-Review and Editing, Y.M. and G.A.; Visualization, R.M.; Supervision, A.D., R.M. and P.M. All authors have read and agreed to the published version of the manuscript.

Funding: This research received no external funding.

Institutional Review Board Statement: Not applicable.

Informed Consent Statement: Not applicable. 
Data Availability Statement: No data were generated.

Conflicts of Interest: The authors declare no conflict of interest.

\section{References}

1. Prince, M.; Bryce, R.; Albanese, E.; Wimo, A.; Ribeiro, W.; Ferri, C.P. The global prevalence of dementia: A systematic review and metaanalysis. Alzheimers Dement. 2013, 1, 63-75. [CrossRef]

2. Adav, S.S.; Sze, S.K. Insight of brain degenerative protein modifications in the pathology of neurodegeneration and dementia by proteomic profiling. Mol. Brain. 2016, 9, 92. [CrossRef] [PubMed]

3. Leandro, P.; Gomes, C.M. Protein misfolding in conformational disorders: Rescue of folding defects and chemical chaperoning Mini Rev. Med. Chem. 2008, 8, 901-911. [CrossRef]

4. Tran, L.; Ha-Duong, T. Exploring the Alzheimer amyloid- $\beta$ peptide conformational ensemble: A review of molecular dynamics approaches. Peptides 2015, 69, 86-91. [CrossRef] [PubMed]

5. Ellisdon, A.M.; Bottomley, S.P. The role of protein misfolding in the pathogenesis of human diseases. IUBMB Life 2004, 56, 119-123. [CrossRef]

6. Wilkins, H.M.; Swerdlow, R.H. Amyloid precursor protein processing and bioenergetics. Brain Res. Bull. 2017, 133, 71-79. [CrossRef]

7. O'Brien, R.J.; Wong, P.C. Amyloid precursor protein processing and Alzheimer's disease. Annu. Rev. Neurosci. 2011, 34, 185-204. [CrossRef]

8. Alonso, A.C.; Zaidi, T.; Grundke-Iqbal, I.; Iqbal, K. Role of abnormally phosphorylated tau in the breakdown of microtubules in Alzheimer's disease. Proc. Natl. Acad. Sci. USA 1994, 91, 5562-5566. [CrossRef] [PubMed]

9. Alonso, A.C.; Grundke-Iqbal, I.; Iqbal, K. Alzheimer's disease hyperphosphorylated tau sequesters normal tau into tangles of filaments and disassembles microtubules. Nat. Med. 1996, 2, 783-787. [CrossRef] [PubMed]

10. Jiang, T.; Yu, J.T.; Tian, Y.; Tan, L. Epidemiology and etiology of Alzheimer's disease: From genetic to non-genetic factors. Curr. Alzheimer Res. 2013, 10, 852-867. [CrossRef]

11. Pan, C.C.; Chu, C.S.; Chen, C.L.; Chuang, Y.C.; Chen, N.C. Factors Affecting Rapid Cognitive Decline in Patients with Alzheimer's Disease: A Longitudinal Follow-Up Study. Int. J. Environ. Res. Public Health 2021, 18, 8576. [CrossRef]

12. Chantanachai, T.; Sturnieks, D.L.; Lord, S.R.; Payne, N.; Webster, L.; Taylor, M.E. Risk factors for falls in older people with cognitive impairment living in the community: Systematic review and meta-analysis. Ageing Res. Rev. 2021, 25, 101452.

13. Profennoa, L.A.; Porsteinsson, A.P.; Faraonea, V. Meta-Analysis of Alzheimer's Disease Risk with Obesity, Diabetes, and Related Disorders. Biol. Psychiatry. 2010, 67, 505-512. [CrossRef]

14. Gil-Montoya, J.A.; Barrios, R.; Santana, S. Association between periodontitis and amyloid $\beta$ peptide in elderly people with and without cognitive impairment. J. Periodontol. 2017, 88, 1051-1058. [CrossRef]

15. Kamer, A.R.; Pirraglia, E.; Tsui, W.; Rusinek, H.; Vallabhajosula, S.; Mosconi, L.; Yi, L.; McHugh, P.; Craig, R.G.; Svetcov, S.; et al. Periodontal disease associates with higher brain amyloid load in normal elderly. Neurobiol. Aging. 2015, 36, 627-633. [CrossRef] [PubMed]

16. Gugnani, S.; Gugnani, N. Tooth loss in Periodontitis: How valuable are the predictors? Evid. Based Dent. 2020, $21,12-13$. [CrossRef] [PubMed]

17. Bansal, T.; Pandey, A.; Deepa, D.; Asthana, A.K. C-Reactive Protein (CRP) and its Association with Periodontal Disease: A Brief Review. J. Clin. Diagn. Res. 2014, 8, 21-24.

18. Cerajewska, T.L.; Davies, M.; West, N.X. Periodontitis: A potential risk factor for Alzheimer's disease. Br. Dent. J. 2015, 218, 29-34. [CrossRef]

19. Ide, M.; Harris, M.; Stevens, A.; Sussams, R.; Hopkins, V.; Culliford, D.; Fuller, J.; Ibbett, P.; Raybould, R.; Thomas, R.; et al. Periodontitis and Cognitive Decline in Alzheimer's Disease. PLoS ONE 2016, 11, e0151081. [CrossRef]

20. Paul, O.; Arora, P.; Mayer, M.; Chatterjee, S. Inflammation in Periodontal Disease: Possible Link to Vascular Disease. Front. Physiol. 2021, 11, 609614. [CrossRef]

21. Choi, S.; Kim, K.; Chang, J. Association of chronic periodontitis on Alzheimer's disease or vascular dementia. J. Am. Geriatr. Soc. 2019, 67, 1234-1239. [CrossRef]

22. Ojeda, J.; Ávila, A.; Vidal, P.M. Gut Microbiota Interaction with the Central Nervous System throughout Life. J. Clin. Med. 2021, 10, 1299. [CrossRef] [PubMed]

23. Schächtle, M.A.; Rosshart, S.P. The Microbiota-Gut-Brain Axis in Health and Disease and Its Implications for Translational Research. Front. Cell Neurosci. 2021, 15, 698172. [CrossRef] [PubMed]

24. Tricco, A.C.; Lillie, E.; Zarin, W.; O’Brien, K.K.; Colquhoun, H.; Levac, D.; Moher, D.; Peters, M.D.J.; Horsley, T.; Weeks, L.; et al. PRISMA Extension for Scoping Reviews (PRISMA-ScR): Checklist and Explanation. Ann. Intern. Med. 2018, 169, 467-473. [CrossRef] [PubMed]

25. Hooks, K.B.; Konsman, J.P.; O’Malley, M.A. Microbiota-gut-brain research: A critical analysis. Behav. Brain Sci. 2018, 42, 60. [CrossRef] [PubMed]

26. Kantarci, A.; Tognoni, C.M.; Yaghmoor, W.; Marghalani, A.; Stephens, D.; Ahn, J.Y.; Carreras, I.; Dedeoglu, A. Microglial response to experimental periodontitis in a murine model of Alzheimer's disease. Sci. Rep. 2020, 10, 18561. [CrossRef] 
27. De Oliveira Araújo, R.; Villoria, G.E.M.; Luiz, R.R.; Esteves, J.C.; Leão, A.T.T.; Feres-Filho, E.J. Association between periodontitis and Alzheimer's disease and its impact on the self-perceived oral health status: A case-control study. Clin. Oral Investig. 2021, 25, 555-562. [CrossRef] [PubMed]

28. De Souza Rolim, T.; Fabri, G.M.C.; Nitrini, R.; Anghinah, R.; Teixeira, M.J.; de Siqueira, J.T.T.; Cestari, J.A.F.; de Siqueira, S.R.D.T. Oral Infections and Orofacial Pain in Alzheimer's Disease: A Case-Control Study. J. Alzheimer's Dis. 2014, 38, 823-829. [CrossRef] [PubMed]

29. Syrjälä, A.-M.H.; Ylöstalo, P.; Ruoppi, P.; Komulainen, K.; Hartikainen, S.; Sulkava, R.; Knuuttila, M. Dementia and Oral Health among Subjects Aged 75 Years or Older. Gerodontology 2012, 29, 36-42. [CrossRef]

30. Holmer, J.; Eriksdotter, M.; Schultzberg, M.; Pussinen, P.J.; Buhlin, K. Association between periodontitis and risk of Alzheimer's disease, mild cognitive impairment, and subjective cognitive decline: A case-control study. J. Clin. Periodontol. 2018, 45, 1287-1298. [CrossRef]

31. Martande, S.S.; Pradeep, A.R.; Singh, S.P.; Kumari, M.; Suke, D.K.; Raju, A.P.; Naik, S.B.; Singh, P.; Guruprasad, C.N.; Chatterji, A. Periodontal Health Condition in Patients with Alzheimer's Disease. Am. J. Alzheimer's Dis. Other. Demen. 2014, 29, 498-502. [CrossRef]

32. Beydoun, M.A.; Beydoun, H.A.; Hossain, S.; El-Hajj, Z.W.; Weiss, J.; Zonderman, A.B. Clinical and Bacterial Markers of Periodontitis and Their Association with Incident All-Cause and Alzheimer's Disease Dementia in a Large National Survey. J. Alzheimers Dis. 2020, 75, 157-172. [CrossRef]

33. Chen, C.K.; Wu, Y.T.; Chang, Y.C. Association between chronic periodontitis and the risk of Alzheimer's disease: A retrospective, population-based, matched-cohort study. Alzheimers Res. Ther. 2017, 9, 56. [CrossRef] [PubMed]

34. Liu, X.X.; Jiao, B.; Liao, X.X.; Guo, L.N.; Yuan, Z.H.; Wang, X.; Xiao, X.W.; Zhang, X.Y.; Tang, B.S.; Shen, L. Analysis of Salivary Microbiome in Patients with Alzheimer's Disease. J. Alzheimers Dis. 2019, 72, 633-640. [CrossRef] [PubMed]

35. Maurer, K.; Rahming, S.; Prvulovic, D. Dental health in advanced age and Alzheimer's Disease: A possible link with bacterial toxins entering the brain? Psychiatry Res. Neuroimaging 2018, 282, 132-133. [CrossRef] [PubMed]

36. Riviere, G.R.; Riviere, K.H.; Smith, K.S. Molecular and immunological evidence of oral Treponema in the human brain and their association with Alzheimer's disease. Oral Microbiol. Immunol. 2002, 17, 113-118. [CrossRef] [PubMed]

37. Ilievski, V.; Zuchowska, P.K.; Green, S.J.; Toth, P.T.; Ragozzino, M.E.; Le, K.; Aljewari, H.W.; O’Brien-Simpson, N.M.; Reynolds, E.C.; Watanabe, K. Chronic oral application of a periodontal pathogen results in brain inflammation, neurodegeneration, and amyloid beta production in wild type mice. PLoS ONE 2018, 13, e0204941. [CrossRef]

38. Noble, J.M.; Scarmeas, N.; Celenti, R.S.; Elkind, M.S.V.; Wright, C.B.; Schupf, N.; Papapanou, P.N. Serum IgG antibody levels to periodontal microbiota are associated with incident Alzheimer disease. PLoS ONE 2014, 9, e114959. [CrossRef]

39. Dominy, S.S.; Lynch, C.; Ermini, F.; Benedyk, M.; Marczyk, A.; Konradi, A.; Nguyen, M.; Haditsch, U.; Raha, D.; Griffin, C.; et al. Porphyromonas Gingivalis in Alzheimer's Disease Brains: Evidence for Disease Causation and Treatment with Small-Molecule Inhibitors. Sci. Adv. 2019, 5, eaau3333. [CrossRef]

40. Yamada, C.; Akkaoui, J.; Ho, A.; Duarte, C.; Deth, R.; Kawai, T.; Nichols, F.; Lakshmana, M.K.; Movila, A. Potential Role of Phosphoglycerol Dihydroceramide Produced by Periodontal Pathogen Porphyromonas gingivalis in the Pathogenesis of Alzheimer's Disease. Front. Immunol. 2020, 11, 591571. [CrossRef] [PubMed]

41. Zhang, S.; Yang, F.; Wang, Z.; Qian, X.; Ji, Y.; Gong, L.; Ge, S.; Yan, F. Poor oral health conditions and cognitive decline: Studies in humans and rats. PLoS ONE 2020, 15, e0234659. [CrossRef] [PubMed]

42. Díaz-Zúñiga, J.; More, J.; Melgar-Rodríguez, S.; Jiménez-Unión, M.; Villalobos-Orchard, F.; Muñoz-Manríquez, C.; Monasterio, G.; Valdés, J.L.; Vernal, R.; Paula-Lima, A. Alzheimer's Disease-Like Pathology Triggered by Porphyromonas gingivalis in Wild Type Rats Is Serotype Dependent. Front. Immunol. 2020, 11, 588036. [CrossRef]

43. Hayashi, K.; Hasegawa, Y.; Takemoto, Y.; Cao, C.; Takeya, H.; Komohara, Y.; Mukasa, A.; Kim-Mitsuyama, S. Continuous intracerebroventricular injection of Porphyromonas gingivalis lipopolysaccharide induces systemic organ dysfunction in a mouse model of Alzheimer's disease. Exp. Gerontol. 2019, 120, 1-5. [CrossRef] [PubMed]

44. Leblhuber, F.; Huemer, J.; Steiner, K.; Gostner, J.M.; Fuchs, D. Knock-on effect of Continuous intracerebroventricular disease? Wien Klin. Wochenschr. 2020, 132, 493-498. [CrossRef] [PubMed]

45. Pape, K.; Tamouza, R.; Leboyer, M.; Zipp, F. Immunoneuropsychiatry: Novel perspectives on brain disorders. Nat. Rev. Neurol. 2019, 15, 317-328. [CrossRef]

46. Cerovic, M.; Forloni, G.; Balducci, C. Neuroinflammation and the Gut Microbiota: Possible Alternative Therapeutic Targets to Counteract Alzheimer's Disease? Front. Aging Neurosci. 2019, 11, 284. [CrossRef]

47. Kamer, A.R.; Craig, R.G.; Pirraglia, E.; Dasanayake, A.P.; Norman, R.G.; Boylan, R.J.; Nehorayoff, A.; Glodzik, L.; Brys, M.; de Leon, M.J. TNF-Alpha and Antibodies to Periodontal Bacteria Discriminate between Alzheimer's Disease Patients and Normal Subjects. J. Neuroimmunol. 2009, 216, 92-97. [CrossRef]

48. Cestari, J.A.; Fabri, G.M.; Kalil, J.; Nitrini, R.; Jacob-Filho, W.; De Siqueira, J.T.; Siqueira, S.R. Oral Infections and Cytokine Levels in Patients with Alzheimer's Disease and Mild Cognitive Impairment Compared with Controls. J. Alzheimers Dis. 2016, 52, 1479-1485. [CrossRef]

49. Poole, S.; Singhrao, S.K.; Kesavalu, L.; Curtis, M.A.; Crean, S. Determining the presence of periodontopathic virulence factors in short-term postmortem Alzheimer's disease brain tissue. J. Alzheimers Dis. 2013, 36, 665-677. [CrossRef] 
50. Laugisch, O.; Johnen, A.; Maldonado, A.; Ehmke, B.; Bürgin, W.; Olsen, I.; Potempa, J.; Sculean, A.; Duning, T.; Eick, S. Periodontal Pathogens and Associated Intrathecal Antibodies in Early Stages of Alzheimer's Disease. J. Alzheimers Dis. 2018, 66, 105-114. [CrossRef]

51. Sims, R.; Hill, M.; Williams, J. The multiplex model of the genetics of Alzheimer's disease. Nat. Neurosci. 2020, 23, 311-322. [CrossRef] [PubMed]

52. Tabrett, A.; Horton, M.W. The influence of host genetics on the microbiome. F1000Research 2020, 9, 84. [CrossRef]

53. Sun, Y.Q.; Richmond, R.C.; Chen, Y.; Mai, X.M. Mixed evidence for the relationship between periodontitis and Alzheimer's disease: A bidirectional Mendelian randomization study. PLoS ONE 2020, 15, e0228206. [CrossRef]

54. Song, X.; Chen, J.; Hou, Z.; Xie, N. Antimicrobial therapy and the potential mechanisms in Alzheimer's disease. Neurosci. Lett. 2021, 741, 135464. [CrossRef]

55. Kowalski, K.; Mulak, A. Brain-Gut-Microbiota Axis in Alzheimer's Disease. J. Neurogastroenterol. Motil. 2019, 25, 48-60. [CrossRef] [PubMed]

56. Holzer, P.; Farzi, A. Neuropeptides and the microbiota-gut-brain axis. Adv. Exp. Med. Biol. 2014, 817, $195-219$.

57. Martin, C.R.; Osadchiy, V.; Kalani, A.; Mayer, E.A. The Brain-Gut-Microbiome Axis. Cell Mol. Gastroenterol. Hepatol. 2018, 6, 133-148. [CrossRef] [PubMed]

58. Gao, S.S.; Chu, C.H.; Young, F.Y.F. Oral Health and Care for Elderly People with Alzheimer's Disease. Int. J. Environ. Res. Public Health 2020, 17, 5713. [CrossRef]

59. Soscia, S.J.; Kirby, J.E.; Washicosky, K.J.; Tucker, S.M.; Ingelsson, M.; Hyman, B.; Burton, M.A.; Goldstein, L.E.; Duong, S.; Tanzi, R.E.; et al. The Alzheimer's disease-associated amyloid beta-protein is an antimicrobial peptide. PLoS ONE 2010, 5, e9505. [CrossRef] [PubMed]

60. Bulgart, H.R.; Neczypor, E.W.; Wold, L.E.; Mackos, A.R. Microbial involvement in Alzheimer disease development and progression. Mol. Neurodegener. 2020, 15, 42. [CrossRef]

61. Gareau, M.G. Cognitive Function and the Microbiome. Int. Rev. Neurobiol. 2016, 131, 227-246. [PubMed]

62. Calsolaro, V.; Edison, P. Neuroinflammation in Alzheimer's disease: Current evidence and future directions. Alzheimers Dement. 2016, 12, 719-732. [CrossRef]

63. Hansen, D.V.; Hanson, J.E.; Sheng, M. Microglia in Alzheimer's disease. J. Cell Biol. 2018, 217, 459-472. [CrossRef] [PubMed]

64. Cooke, J.P. Inflammation and Its Role in Regeneration and Repair. Circ. Res. 2019, 124, 1166-1168. [CrossRef]

65. Levin, B.R.; Baquero, F.; Ankomah, P.P.; Mc Call, I.C. Phagocytes, Antibiotics, and Self-Limiting Bacterial Infections. Trends Microbiol. 2017, 25, 878-892. [CrossRef]

66. Levin, B.R.; Antia, R. Why we don't get sick: The within-host population dynamics of bacterial infections. Science 2001, 292, 1112-1115. [CrossRef]

67. Cunliffe, J. Intentional pathogen killing-or denial of substrate? Scand. J. Immunol. 2007, 66, 604-609. [CrossRef]

68. Horliana, A.C.; Chambrone, L.; Foz, A.M.; Artese, H.P.; Rabelo Mde, S.; Pannuti, C.M.; Romito, G.A. Dissemination of periodontal pathogens in the bloodstream after periodontal procedures: A systematic review. PLoS ONE 2014, 9, e98271. [CrossRef] [PubMed]

69. Berg, R.D. Bacterial Translocation from the Gastrointestinal Tract; Springer: Boston, MA, USA, 1999; pp. 11-50.

70. Rhodes, A.; Evans, L.E.; Alhazzani, W.; Levy, M.M.; Antonelli, M.; Ferrer, R.; Kumar, A.; Sevransky, J.E.; Sprung, C.L.; Nunnally, M.E.; et al. Surviving Sepsis Campaign: International Guidelines for Management of Sepsis and Septic Shock: 2016. Intensive Care Med. 2017, 43, 304-377. [CrossRef]

71. Maurer, P.; Hoffman, E.; Mast, H. Bacterial meningitis after tooth extraction. Br. Dent. J. 2009, 206, 69-71. [CrossRef]

72. Kim, K.S. Microbial translocation of the blood-brain barrier. Int. J. Parasitol. 2006, 36, 607-614. [CrossRef]

73. Logsdon, A.F.; Erickson, M.A.; Rhea, E.M.; Salameh, T.S.; Banks, W.A. Gut reactions: How the blood-brain barrier connects the microbiome and the brain. Exp. Biol. Med. 2018, 243, 159-165. [CrossRef]

74. Montagne, A.; Zhao, Z.; Zlokovic, B.V. Alzheimer's disease: A matter of blood-brain barrier dysfunction? J. Exp. Med. 2017, 214, 3151-3169. [CrossRef]

75. Singhrao, S.K.; Harding, A.; Chukkapalli, S.; Olsen, I.; Kesavalu, L.; Crean, S. Apolipoprotein E Related Co-Morbidities and Alzheimer's Disease. J. Alzheimers Dis. 2016, 51, 935-948. [CrossRef]

76. Humphries, D.L.; Scott, M.E.; Vermund, S.H. Pathways Linking Nutritional Status and Infectious Disease: Causal and Conceptual Frameworks; Humana Press: Totowa, NJ, USA, 2020; pp. 3-22.

77. Yu, B.; Yu, L.; Klionsky, D.J. Nutrition acquisition by human immunity, transient overnutrition and the cytokine storm in severe cases of COVID-19. Med. Hypotheses 2021, 155, 110668. [CrossRef] [PubMed]

78. Breijyeh, Z.; Karaman, R. Comprehensive Review on Alzheimer's Disease: Causes and Treatment. Molecules 2020, $25,5789$. [CrossRef]

79. Routier, A.; Blaizot, A.; Agossa, K.; Dubar, M. What do we know about the mechanisms of action of probiotics on factors involved in the pathogenesis of periodontitis? A scoping review of in vitro studies. Arch. Oral Biol. 2021, 129, 105196. [CrossRef] [PubMed]

80. Soukos, N.S.; Stultz, J.; Abernethy, A.D.; Goodson, J.M. Phototargeting human periodontal pathogens in vivo. Lasers Med. Sci. 2015, 30, 943-952. [CrossRef]

81. Soukos, N.S.; Som, S.; Abernethy, A.D.; Ruggiero, K.; Dunham, J.; Lee, C.; Doukas, A.G.; Goodson, J.M. Phototargeting oral black-pigmented bacteria. Antimicrob. Agents Chemother. 2005, 49, 1391-1396. [CrossRef] [PubMed] 
82. Maitre, Y.; Mahalli, R.; Micheneau, P.; Delpierre, A.; Guerin, M.; Amador, G.; Denis, F. Pre- and Probiotics Involved in the Modulation of Oral Bacterial Species: New Therapeutic Leads in Mental Disorders? Microorganisms 2021, 9, 1450. [CrossRef]

83. Godoy, J.A.; Rios, J.A.; Zolezzi, J.M.; Braidy, N.; Inestrosa, N.C. Signaling pathway cross talk in Alzheimer's disease. Cell Commun. Signal. 2014, 12, 23. [CrossRef] [PubMed]

84. Jiang, C.; Li, G.; Huang, P.; Liu, Z.; Zhao, B. The Gut Microbiota and Alzheimer's Disease. J. Alzheimer's Dis. 2017, 58, 1-15. [CrossRef] [PubMed]

85. Friedland, R.P.; Chapman, M.R. The role of microbial amyloid in neurodegeneration. PLoS Pathog. 2017, 13, e1006654. [CrossRef] [PubMed]

86. O'Toole, P.W.; Jeffery, I.B. Gut microbiota and aging. Science 2015, 350, 1214-1215. [CrossRef]

87. Brennan, L.J.; Strauss, J. Cognitive impairment in older adults and oral health considerations: Treatment and management. Dent. Clin. N. Am. 2014, 58, 815-828. [CrossRef] [PubMed]

88. Fereshtehnejad, S.M.; Garcia-Ptacek, S.; Religa, D.; Holmer, J.; Buhlin, K.; Eriksdotter, M.; Sandborgh-Englund, G. Dental care utilization in patients with different types of dementia: A longitudinal nationwide study of 58,037 individuals. Alzheimers Dement. 2018, 14, 10-19. [CrossRef]

89. Prince, M.; Wimo, A.; Guerchet, M.; Ali, G.-C.; Wu, Y.-T.; Matthew, P. World Alzheimer Report 2015, The Global Impact of Dementia: An Analysis of Prevalence, Incidence, Cost and Trends. Alzheimer's Dis. Int. 2015, 87, 84.

90. Martínez-Cué, C.; Rueda, N. Signalling Pathways Implicated in Alzheimer's Disease Neurodegeneration in Individuals with and without Down Syndrome. Int. J. Mol. Sci. 2020, 21, 6906. [CrossRef] [PubMed] 